\title{
Effects of Banning Corporal Punishment on Discipline in South African Schools: A Case Study of Secondary Schools in Sekhukhune District, Limpopo Province
}

\author{
Tiny Lesheleba Ntuli \\ Department of educational leadership and management \\ College of education, University of South Africa \\ 30872626@mylife.ac.za \\ Pertunia Rebotile Machaisa \\ Department of educational leadership and management \\ College of education, University of South Africa \\ machapr@unisa.ac.za
}

Doi:10.5901/mjss.2014.v5n23p1781

\begin{abstract}
The banning of corporal punishment in South African schools sparked an intense debate after 1996. Legislation was put into operation to this effect and educators and all stakeholders in education were mandated to abide. Prior research and literature show that since the abolition of corporal punishment, there has been a deterioration of discipline in schools. This article addresses this argument and through the use of qualitative focus-group interviews with educators, it is revealed that there is indeed a decline in the level of discipline in schools since the prohibition of corporal punishment. It was also discovered that there is a predicament in applying contemporary disciplinary measures due to, among other reasons, a lack of training and in some cases minimal training regarding alternatives to corporal punishment provided by the Department of Education and the ambiguity thereof.
\end{abstract}

Keywords: corporal punishment, school discipline, educators, positive discipline practices, alternatives to corporal punishment

\section{Introduction}

Corporal punishment as a disciplinary strategy is commonly used in many parts of the world (Pinheiro, 2006 in Johnson Frankenberg \& Holmqvist, 2010). However, the use of corporal punishment was abolished in South African schools in 1996 as it was regarded as violation of children's rights. According to the Department of Education policy (2000) corporal punishment is defined as "any deliberate act against a child that inflicts pain or physical discomfort to punish or contain him or her". These deliberate acts can include, among others, hitting with either a hand, using an object such as a cane, belt, whip or shoe. This practice was declared unconstitutional in 1996 as pointed out in the Constitution of the Republic of South Africa Act 108 of 1996 (section 10 and 12). Corporal punishment was legally abolished and its prohibition adopted into law in 1999 through the South African Schools Act 84 of 1996 (section 10). There has, however, been an indication in literature that the banning of corporal punishment has had a direct impact on the escalating discipline problems in schools. According to Maphosa and Shumba (2010) it has become increasingly difficult for educators to ensure discipline in schools as a result of the banning of corporal punishment.

It has also been observed that as soon as this law came into operation and learners were made aware of it, the state of unruliness in schools escalated (Masita, 2008). This has also been confirmed by Matoti (2010) where he states "the abolition of corporal punishment has a negative impact on schools discipline. He further states that learners bring dangerous weapons to school, endangering the lives of everyone. In this way educators become unhappy, demoralised and exhausted (Naong, 2007). The aim of this article to: (1) discuss the possible effects of the relationship between the banning of corporal punishment and school discipline; (2) suggest positive discipline practices that can be used in schools in the absence of corporal punishment; and (3) describe the critical role of educators in managing discipline in schools. This article argues that since the banning of corporal punishment, there has been an alarming increase in the lack of discipline in schools. It should also be noted that since the law should be upheld and respected, there should be alternative measures put in place to replace corporal punishment and instil positive discipline without infringing on the children's rights. This article consists of three sections. In the first section, we explore literature review on school 
discipline and the banning of corporal punishment. In the second section, we provide the research methodology used in this qualitative study. And lastly, we present the research findings and discussion.

\section{Literature Review}

\subsection{Defining corporal punishment}

Corporal punishment refers to the intentional application of physical pain as a method to change behaviour and includes a wide variety of methods such as hitting, slapping, punching, kicking, pinching, shaking and shoving, among others (Middleton, 2008 in Jwan, 2011). Furthermore, corporal punishment is explained as the use of physical force with the intention of causing a child to experience pain, but not injury, for purposes of correction or control of the child's behaviour (Paolucci \& Violato, 2004 in Jwan, 2011; Strauss \& Donnelly as cited by McClure \& May, 2008; Straus, 1994). Maree (1999) defines corporal punishment as "physical punishment as distinguished from pecuniary punishment or a fine; any kind of punishment of or inflicted on the body" or "the intention of pain by a teacher or other educational official upon the body of a student as a penalty for doing something which has been disapproved of by the punisher". This definition is very relevant to schools as the punisher (teacher) inflicts some kind of pain on the person perceived to have done something wrong and or unacceptable. This has been the case in South African schools for a while now. However, with the passing of laws prohibiting corporal punishment, this practice has been minimised. There is however, evidence that this kind of punishment still persists in some South African schools although abolished (Morrell, 2001; Van Wyk, 2001; Maree, 2004).

According to Porteus, Vally and Ruth (2001), the context of South African school discipline has a rather narrow meaning. They explain that school discipline in South Africa is equated to punishment often physical in nature or even psychological, for instance humiliation. Joubert, De Wall and Rossouw (2004) state that the concepts "discipline" and "punishment" have different meanings although they are sometimes used interchangeably. This statement points out a worrying concern that for discipline to be instilled in South African schools, there must be some degree of punishment. This cannot be the case because discipline and punishment have different meanings and connotations. While on one hand discipline is about positive behaviour management which is aimed at promoting appropriate behaviour and developing self-discipline and self-control in learners (Squelch as cited by Joubert et al. 2004); punishment on the other hand is a component or form of discipline (Rogers 1998) that involves actions taken in response to inappropriate behaviour in order to correct or modify and restore harmonious relations (Joubert et al., 2004). It is therefore generally acceptable in most schools that when learners conduct themselves in a way that is assumed to be unacceptable, those learners are expected to be punished.

Some educators still practice corporal punishment as a measure to control learner behaviour which in some instances is perceived as unruly or out of order. Most educators assume that corporal punishment can mend a child's behaviour. Bauer, Dubanoski, Yamauchi and Honbo (1990) explain that most teachers motivate the practice of corporal punishment as they believe it enhances character development. These teachers believe corporal punishment is effective, quick and relatively easy; achieves temporary compliance, makes people feel powerful, contributes to rapid reduction or elimination of unwanted behavioural patterns (Porteus, Vally \& Ruth, 2001; Rose, 1989; Strauss, 1994). These authors also are of the view that teachers who practice corporal punishment mentioned that it is only needed as a last resort. They regard corporal punishment as harmless, inducing respect and the only language that children understand.

Biblically, the ideal of morality and character development laid a foundation for the justification of corporal punishment in South Africa (Maree, 2004). Maree further alludes to the fact that the word discipline in the Bible is mistakenly equated to the concept of corporal punishment. If this explanation is considered, it means educators should easily adopt the use of corporal punishment as a solution to discipline challenges in schools. It means for learners to be disciplined, teachers need to use the force of corporal punishment to ensure stability and good behaviour. Hunt (1999) dismisses this argument by stating the fact that Jesus saw children as being close to God and urged love, but not punishment. The issue around Christianity and the practice of corporal punishment has been contested for many years in different parts of the world (Jwan, 2011).

\subsection{Legislative implication of corporal punishment in South African schools}

One of the most critical reasons why corporal punishment is a topic worthy of being studied is because of the potential negative effects it may cause (Owen, 2005). These negative effects are mostly based on the violation of human rights. According to Guidelines on Human Rights Education for Secondary Schools systems (2012), schools should be places 
where the dignity of every child is upheld and where knowledge about human rights is connected to the opportunity to experience human rights in everyday school life. This means the human rights play a crucial role in ensuring the development of a child in a school environment and thus must be protected. The United Nations Convention on the Rights of the Child and its application is among other elements ensuring this. In the same vein, the Universal Declaration of Human Rights upholds, among other rights, peace and security, freedom from all forms of violence and the promotion of the child's best interest. The United Nations Committee on the Rights of the Child considers corporal punishment as a violation of article 19 of the Convention on the Rights of the Child which clearly states that children should be protected against physical as well as psychological violence (Johnson Frankenberg \& Holmqvist, 2010).

Maphosa and Shumba (2010) emphasise that with the democratisation of the South African school system, which is in line with the new democratic constitution, much emphasis has been put on the respect and preservation of children's rights. These authors further explain that South Africa as a signatory to the Convention on the Rights of the Child has an obligation to pass laws and take social, educational and administrative measures to protect the child. To meet this obligation, the country abolished corporal punishment as a means to adhere to the mandate. The South African Constitution (section 12) states that: "everyone has the right not to be treated or punished in a cruel, inhuman or degrading way". The National Education Policy Act (27 of 1996) also stipulates that: "no person shall administer corporal punishment or subject a student to physical abuse at any educational institution." The South African Schools Act (SASA) (84 of 1996) states that: (1) "no person may administer corporal punishment at a school to a learner; (2) any person who contravenes subsection 1 is guilty of an offence and liable on conviction to a sentence which could be imposed for assault".

In addition, The African Charter on the Rights and Welfare of the Child (1999: Article 16) postulates that: "States Parties to the present Charter shall take specific legislative, administrative, social and educational measures to protect the child from all forms of torture, inhumane or degrading treatment and especially physical or mental injury or abuse, neglect or maltreatment including sexual abuse, while in the care of the child". The Charter (1999: Article 11, s.5) also adds that its member countries must take steps to ensure that a child who is subjected to school or parental discipline is treated with humanity and respect for the inherent dignity of the child. South African as well as some international law has created a new legal context and it is important for principals and educators to know the law relating to school discipline and punishment, and to be familiar with legal concepts, principles and procedures so that they can continue building and maintaining effective schools (Joubert, De Waal \& Rossouw, 2005).

\subsection{Effects of the relationship between banning corporal punishment and school discipline}

Prior research shows that cases of learner indiscipline are on the increase in South African schools (Harber, 2001; Zulu, Urbani, van der Merwe \& van der Walt, 2004; Maphosa \& Shumba, 2010). They further allude that educators generally feel disempowered in their ability to maintain discipline in schools in the absence of corporal punishment. After the banning of corporal punishment in schools under the South African Schools Act (84 of 1996), lack of discipline and safety in schools became one of the major challenges. It has become increasingly difficult for educators to ensure discipline in schools as a result of the banning of corporal punishment (Maphosa \& Shumba, 2010). Makapela (2006) points out those learners literally take advantage of educators because they are fully aware that whatever punishment is given, will not equal the pain of corporal punishment. The study by Maphosa and Shumba (2010) revealed that learners had neither fear nor respect for educators and behaved as they pleased. This behaviour, they explain, signals a recipe for chaos in schools. The above mentioned studies and others in this area of research have come to the conclusion that learners in South African schools are out of control because they are well aware that no matter how bad and unbecoming their actions are, they will never face the severe consequences of corporal punishment. Some teachers believe that behavioural problems increase in the absence of corporal punishment (Strauss, 1994).

Educators who previously relied on corporal punishment now have to develop alternative methods of coping with discipline problems (Naong, 2007). Educators feel disempowered by the outlawing of corporal punishment. According to Ndamani (2008), lack of discipline or challenging behaviour in secondary schools and classrooms is one of the serious problems experienced by educators. This challenging behaviour results in educators feeling helpless and disempowered, and this may lead to unsuccessful teaching and learning. It is also perceived that from the time learners became aware that corporal punishment had been abolished, their misbehaviour escalated to the extent that currently a state of unruliness prevails (Masitsa, 2008). Maphosa and Shumba (2010) also state that the thrust on children's rights and subsequent banning of corporal punishment has ushered in an era of licentiousness in learners as they no longer have respect for their educators.

The abolition of corporal punishment has a negative impact on school discipline. Matoti (2010) confirms that 
learners do not respect educators and they bring dangerous weapons to school, endangering everybody's lives. Moreover, educators in South Africa are generally unhappy, demoralised and exhausted (Naong, 2007). Due to lack of discipline, equivocal policies, and licentiousness displayed by learners, the schools also experience gangsterism, teenage pregnancies, hooligan behaviour and abhorrent graffiti, learners' lack of commitment on their work leading to most secondary schools being dysfunctional. They further experience the dismissal of educators and a high learner dropout rate.

\subsection{Positive discipline practices in the absence of corporal punishment}

Recently most schools have moved away from corporal punishment as a disciplinary action and rely more on alternative forms of punishment such as in-school suspension, after-school detention, and other wide range of punishments (McClure \& May, 2008). Discipline should be thought of as a means of teaching learners to take positive charge of their lives (Charles, 2007). Charles (2007) further asserts that good discipline shows learners what they have done wrong; has them assume ownership of the problem that has resulted; and teaches them ways to solve the problem; all the while leaving their personal dignity intact. The purpose of discipline should be constructive rather than destructive. According to Porter (2004), the purpose of discipline is a largely managerial one which is creating order. Establishing order in a school is essential for effective teaching and learning. Learners learn most successfully in an orderly, well-organised environment. Mtsweni (2008) concurs, stating that discipline is necessary for maintaining order and harmony in the classroom situation. The author further asserts that learners learn best in an orderly and safe environment. Discipline is considered to be educative in nature rather than punitive. Masitsa (2008) comments that discipline is part of an educative order. Soneson (2005) also indicates that giving praise when children obey or when they do things right encourages them to model their behaviour on positive reinforcement, and it encourages them to learn self-discipline. Self-discipline is certainly the end product of positive and constructive discipline, and Mokhele (2006) suggests that positive, constructive discipline should promote the development of self-discipline.

The management of discipline consequently calls on educators to make learners feel emotionally comfortable and physically safe (Mokhele, 2006). Managing discipline in schools provides learners with safety assurance. Olley, Cohn and Cowan (2010) agree that learners are better able to learn when they feel safe and supported. Mtsweni (2008) also maintains that learners learn best in an orderly and safe environment. Le Mottee (2005) states that discipline has nothing to do with controlling disruptive or other unacceptable behaviour, but with ensuring a "safe and valuing environment so that the rights and needs of people are respected, vindicated and safeguarded". Ndamani (2008) concludes that if both parents and the school are supportive of each other over the learner discipline matters, most of the discipline issues at the school can be easily and quickly resolved.

The manual, "The alternatives to corporal punishment" was introduced by the Department of Education in 2000.This document is intended to assist educators to find more constructive ways of managing discipline in schools. It outlines the legislation that prohibits corporal punishment. It also provides guidelines on alternatives to corporal punishment; and disciplinary measures and procedures. This leaves schools with the responsibility of identifying and implementing alternative disciplinary practices and procedures (Department of Education, 2000). It means that educators should refrain from discipline which is punitive and punishment-oriented. The management of discipline therefore calls on educators to make children feel emotionally comfortable and physically safe so that they (learners) can develop selfdiscipline (intrinsic discipline) and accountability in their actions (Mokhele, 2006).

The Department of Education (2000) encourages educators to implement a proactive approach to put things in place which will safeguard the culture of learning and teaching in their classrooms. The manual suggests the following strategies which will set the stage for a positive learning environment and that can significantly reduce problems with discipline in the classroom: preparing for lessons; exercising self- discipline; having extension work available; ensuring that teaching and learning happen consistently; ensuring that learners are stimulated; establishing class rules with the learners; making a space for time out or a conflict resolution corner; affirming learners; and building positive relationships with learners.

\subsection{Critical role of educators in managing discipline in schools}

Educators have various roles in managing and maintaining discipline in schools. Educator's roles in managing discipline may include, among other responsibilities, assisting in developing a school discipline policy; establishing classroom rules together with the learners; maintaining discipline in the classroom; assisting in handling administrative matters relating to learner discipline; liaising with the principal, other educators and the parents concerning the behaviour of the learner; 
strengthening the school discipline; working in collaboration with other educators in managing learners with behavioural problems; implementing the school discipline policy and school rules; joining forces with parents of learners with behavioural problems in helping the learners overcome their difficulties; assisting in reviewing the school discipline policy and school rules according to the needs of the learners, the school and the community; and acting as an advisor on learner discipline matters.

Adams (2004) highlights some of the educators' key roles in learner discipline which emanated from educators' responses: Educators must have a common goal and all must make the effort to work together. A functional discipline policy must be implemented. The code of conduct must be enforced. Learners should be constantly reminded of the rules. All educators must be in their classes, and not duplicate work, take money to the office or visit another educator during teaching time. There must be a collective effort from all staff members. The consequences of transgressing should be communicated to the learners and enforced. Educators must be exemplary and consistent in enforcing discipline. A proper learning environment should be created. Greater parental involvement should be encouraged. Learners should be praised for good behaviour and stick to what has been decided by the school authorities. Mtsweni (2008) states that educators have the responsibility to maintain discipline at all times in schools and classrooms so that the education of learners flourishes without disruptive behaviour and offences. They also have the greatest responsibility to inculcate, among learners, acceptable values of life such as co-operation, friendliness, love of justice, love of truth and appreciation of the contributions of others.

Furthermore, of importance is the educator - learner relationships which appear to be an integral feature in the management of discipline in public high schools (Mokhele, 2006). Positive educator - learner relationships have the potential of creating a conducive learning environment in the classroom and will determine whether or not a learner benefits from the teaching-learning situation (Mokhele, 2006). A positive relationship between educators and learners is imperative for effective teaching and learning. Poor relationships between educators and learners will lead to an escalation of disciplinary problems which, in turn, will impact negatively on learner performance. Educators should first understand that learners are unique beings with various capabilities, skills, behavioural problems and backgrounds. Therefore educators should treat them as such to create mutual relationships built on mutual trust.

In the classroom situation there must be a positive rapport between educators and learners so that effective teaching and learning can take place (Mtsweni, 2008). The author further indicates that educator-learner relationships should be characterized by caring, a positive school climate, listening, critical questioning, openness and a feeling of being cared for. This will result in improved behaviour, self-confidence, reduction of absenteeism, reduced dropout rates and good performance. An educator's inability to control a learner or class prevents the process of education and learning from happening. Blandford (1998) further states that the ability to maintain an orderly, disciplined classroom environment is essential if efficient teaching and learning are to occur.

\section{Research Design and Methodology}

The following section will briefly describe the research paradigm and approach employed in this article. Data collection strategies, procedures and sampling procedures will be explained. The data analysis process will be highlighted and ethical consideration for this paper will be elaborated on.

\subsection{Research paradigm and research approach}

Qualitative research approach was employed in this article. Data was collected using face-to-face interviews by interacting with selected respondents in their natural settings. A qualitative approach stems from an anti-positivistic, interpretative approach, is idiographic and thus holistic in nature, and aims mainly to understand social phenomena and the meaning that people attach to everyday life (Fouché \& Delport, 2003). Therefore in the case of this article, qualitative approach was used to explore the behaviour, beliefs, perceptions and experiences of the participants regarding the management of school discipline in the absence of corporal punishment.

\subsection{Procedures and instruments for data collection}

Firstly, a review of literature was used to document the importance of the topic. A qualitative review simply introduces the purpose of the study and the initial broad questions that will be reformulated during data collection (McMillan \& Schumacher, 2006). Both primary and secondary literature was studied in order to establish what other scholars have already gathered with regards to the topic. 
Secondly, in-depth individual interviews consisting of open-response questions were used in order to obtain data of participants' meaning on how individuals conceive their world and how they explain or make sense of the important events in their lives (McMillan \& Schumacher, 2006). The in-depth interviews were conducted with individual persons. In this case school principals from four participating schools ) were selected to understand their life experiences regarding school discipline in the absence of corporal punishment, as expressed in their own words. Ragin and Amoroso (2011) also concur that a researcher conducts interviews to hear how people in the research setting make sense of their lives, work, and relationships.

Thirdly, focus group discussions were conducted to obtain a better understanding of the problem. In these discussions, participants deliberated on how discipline has been managed in their schools since the abolition of corporal punishment. They also discussed methods which they find useful in managing discipline. These participants were purposively selected taking into account the grade they teach in, years of teaching experience and the disciplinary problems they have experienced. These educators had certain characteristics in common that relate to the topic of the focus group (Greeff, 2003), so the interaction with the group would therefore lead to data and outcome. Focus group discussions were used as a data collection method to obtain a better understanding of the issue under discussion. The participants discussed how discipline has been managed in their schools since the abolition of corporal punishment and discussed methods which they found useful in managing discipline. Four focus group discussions consisting of six participants from each of the sampled schools were conducted.

\subsection{Sampling}

The idea behind qualitative research is to purposefully select participants or sites (or documents or visual material) that will best help the researcher understand the problem and the research question (Creswell, 2009). Therefore purposeful sampling was used. Accordingly, four secondary schools were purposefully selected for this research: two schools with good grade 12 results and two with poor grade 12 results for the past 5 years. These two types of schools were selected because it is assumed that in schools where better results are produced, effective teaching and learning is taking place due to good discipline, while poor results are the end product of ineffective teaching and learning because of poor discipline. Schools with disciplinary problems are unlikely to produce good results. Twenty-four educators comprising of six educators from each sampled secondary schools in Sekhukhune district were selected. Participants are normally selected because they have certain characteristics in common that relate to the topic of the focus group (Greeff, 2003), so the interaction with the group therefore lead to data and outcome. Focus group interviews were used to empower participants to speak out in their own words as they were regarded as being knowledgeable on the topic.

Theoretical or purposeful sampling was used in this article by means of purposively selecting four public secondary schools. Four principals and 24 educators (six educators from each school) of secondary schools within Sekhukhune district were selected. Principals and educators were appropriate as the research was about alternative ways of managing discipline in the absence of corporal punishment. Four focus group discussions consisting of six participants from each purposively selected school were conducted. Four individual interviews were conducted. All principals of the sampled schools formed part of the individual interviews. In total, 28 respondents participated in this research. McMillan and Schumacher (2010) state that researchers search for information-rich key informants, groups, places or events to study; and these samples are chosen because they are likely to be knowledgeable and informative about the phenomena the researcher is investigating. On the basis of the above statement, principals and educators were chosen for the purpose of this research because they have in-depth knowledge about school discipline and are involved daily in the issue of discipline.

\subsection{Procedures of data analysis}

Qualitative data analysis in this study involved organising, accounting for and explaining the data. In short, making sense of the data in terms of participants' definitions of the situation, noting patterns, themes, categories and regularities (Cohen, Manion \& Morrison, 2008). For the purpose of this article, five steps for qualitative data analysis by McMillan and Schumacher (2010) were adapted. They are as follows: 1. Data organisation- whereby data collected during interviews is organised and analysed later. Organising the data separates it into a few workable units. The interview responses are organised separately to be compared later in the process; 2 . Data transcription - here collected data is transcribed to convert it into a format that would facilitate analysis; 3 . Coding - in this stage data coding begins by identifying small pieces of data that stand alone. These data parts, called segments, divide the dataset. Segments are then analysed to come up with codes so that each segment is labelled by at least one code (some segments have more than one code). 
In this phase data needs to be coded to provide meaning to the segment for easy interpretation; 4. Forming categories or themes - in this phase categories are entities comprised of grouped codes. A single category is used to give meaning to codes that are combined. The author divided the data collected into categories as data analysis involves "breaking up" the data into manageable themes, trends and relationships; to show similarities and dissimilarities for easy identification; and lastly, 5. Discovering patterns - A pattern is a relationship among categories. In searching for patterns, researchers try to understand the complex links among various aspects of people's situations, mental processes, beliefs, and actions. The major patterns serve as the framework for reporting the findings and organising the reports. The patterns assisted the author to consider what was really important and meaningful in the data.

\subsection{Ethical considerations}

The domain of research ethics is concerned with protection of the rights and interest of research participants (Mouton, 1996). According to McMillan and Schumacher (2006), the researcher is ethically responsible for protecting the rights and welfare of the subjects who participate in a study, which involves issues of physical and mental discomfort, harm, and danger. Therefore, the researcher should ensure that the planned research is ethically accountable, that is it conforms to acceptable norms and values. The researcher should also ensure the protection of the rights and welfare of the participants. The following research ethics were taken into account.

\subsubsection{Informed consent and permission}

According to Ragin and Amoroso (2011), to prove that individuals are entering research studies voluntarily and adequately informed, researchers are often required to obtain informed consent from all participants or the participants' legally authorized representatives. Furthermore, to obtain informed consent, researchers must clearly communicate the research procedure, purposes, risks, and benefits to the participants in "jargon-free" language. Also, researchers must clearly communicate that participation is voluntary and that the participant can withdraw at any time (Ragin \& Amoroso, 2011). Using the above outlined facts as a guideline, permission to conduct the research was obtained from the Department of Education at district level (Sekhukhune District) and from the individual participants. In gaining permission the author gave participants assurances of confidentiality and anonymity and described the intended use of the data. The participants also completed and signed informed consent forms as proof that they had been informed of the study details.

\subsubsection{Privacy, confidentiality and anonymity}

Privacy of research participants must be protected (McMillan \& Schumacher, 2010). These scholars further mention that access to participants' characteristics, responses, behaviour, and other information is restricted to the researcher. Accordingly privacy is ensured by applying three practices: anonymity, confidentiality and appropriate storing of data. It was ensured that the information provided by participants in no way revealed their identity, as supported by Cohen et al. (2008). The participants were assured that they would remain anonymous. Data collected was not linked to participants' names. Confidential information was treated as such. The researcher allowed no-one to access the collected data or the names of the participants. The participant's right to privacy was respected and protected by also informing them that they had the right to refuse to take part in the research; to limit time needed for participation; to refuse to answer any questions they deemed uncomfortable and to be interviewed if they are uncomfortable do it.

\section{Research Findings and Discussion}

Research conducted has shown that school discipline is a form of discipline appropriate for highlighting rules and regulations for learners and ensuring order in schools. So, effective and efficient management of discipline in schools will eventually lead to effective teaching and learning. This will automatically anticipate good learner performance. The research has revealed that lack of discipline and safety in schools has become one of the major challenges in South Africa. Therefore, creating and maintaining a safe, disciplined school environment was identified as the most crucial issue in schools. Managing discipline in schools is therefore of the outmost importance to allow effective teaching and learning. Moreover, the management of discipline in schools is central to effective teaching and learning. With the banning of corporal punishment in schools, most educators are of the view that there has been a lack of control of discipline in schools, hence the topic under discussion. Participants in this research proved that there is a lack of discipline in schools and they put the blame on the abolishment of corporal punishment. They are very much aware that corporal punishment 
has been removed in schools as the law dictates.

It emerged that since they cannot use any kind of force or harsh punishment to instil discipline in their schools, they would rather come up with their own possible solutions to the problem of indiscipline. It is however, to be noted that educators displayed diverse understanding of alternatives to corporal punishment, especially on their effectiveness. They were of the view that these alternatives are not helpful to them as they are unclear and ambiguous. The respondents maintain that there is a need for a systematic plan and thorough research on the abolition of corporal punishment. This implies that the introduction of alternative methods to corporal punishment was done haphazardly without proper planning and training. One of the key findings of this research is that educators and principals find it difficult to apply the alternative methods. The respondents were well aware that corporal punishment is outlawed in South African schools, but it is apparent that their problem is that there is insufficient training and in most cases there is no training at all on the alternatives to corporal punishment. Educators and principals who took part in the research had diverse understanding of alternatives to corporal punishment. It emerged from the results that the effectiveness of these disciplinary procedures' depends on the types of learners; the type of environment where the school is situated; and how parents instil discipline at home. It also emerged in data that the alternatives to corporal punishment were not well defined. So, it is crucial that the government should establish common methods of managing discipline for schools to apply.

According to the respondents, alternatives to corporal punishment are time consuming. It is evident that these disciplinary measures are strenuous because educators are compelled to leave learners who need their assistance and concentrate on learners with disciplinary problems. Respondents identified the following alternative methods of discipline in their schools. These methods include amongst others: inviting parents to school; giving learners lighter work for example sweeping, picking up papers, detention, extra work given, verbal warning, a written reprimand, mentorship, sworn statement, involving a disciplinary committee, exclusion from other activities, public confession, suspension; and inviting stakeholders to give motivational talks. Although these methods were mentioned, some are regarded as ineffective. This implies that some methods of discipline are valued more than others. Participants also mentioned the importance of the Code of Conduct as the legal instrument regulating the maintenance of discipline in the school. Therefore, it was emphasised that it is important for schools to have rules to regulate the behaviour of the learners. This will assist in solving the disciplinary problems experienced by the schools.

One area of interest that was stressed by the participants was that disciplinary problems can be curbed in secondary schools if the schools ensure among others; a safe environment and proper security, good classroom management, good educator-learner relationship, good curriculum, involving parents, that learners be encouraged to develop self-control and self-discipline and good communication amongst all stakeholders. The following are possible suggested strategies that can promote positive behaviour in schools in the absence of corporal punishment: Awarding certificates and trophies for work well done and good behaviour. This will undoubtedly assist learners to improve and sustain their good behaviour. Learners tend to become motivated when they are recognised. Involving learners in making the school rules, e.g. developing the Code of Conduct and establishing the classroom rules. By involving learners in rulemaking, learners will realise that their contributions are valued. So, this will automatically appeal to their cooperation and voluntary participation in rule-making. Motivation, e.g. praising and encouraging them. Learners become more determined if they are praised, encouraged and motivated for work well done. Other learners will also strive to achieve that. Adults (educators, parents, principal) modelling and explaining positive behaviour. Children learn by imitating people, especially adults. So, it is most crucial that all adults model good behaviour. Therefore, learners will more easily be able to acquire good behaviour. Introduction of various sporting activities. Since children like exploring, each should be encouraged to take part in two or more activities. If various sporting activities can be introduced, learners will be maximally and fully engaged every day. This will then assist in minimising disciplinary problems in schools.

Encouraging learners to join religious organisations within the school, for instance, the School Christian Organisation, or any other religious movements within the school. By joining these religious organisations, learners will be spiritually empowered. Some learners will certainly be well behaved. A variety of rewards for positive behaviour, including lunch with a friend, homework passes, free time in the gym, or a chance to read outside. These practises will assist in improving learner behaviour in schools. Every learner will be encouraged to be well behaved so that he or she can qualify for such a reward. Respecting rights as a reciprocal process for learners to understand the importance of respecting other people's rights. Learners should be taught to respect other peoples' rights and educators should also respect the learners' rights. This will make learners understand the importance of respecting other people's rights. Should these crucial strategies be applied at schools, learners are likely to redirect their behaviour for a good cause. Ultimately learners' behaviour will improve significantly because the main focus will be on positive mechanisms. Since effective discipline management is central to effective teaching and learning, improvement in learner performance could be anticipated. 


\section{Conclusion}

Corporal punishment and the use of other punitive measures are often regarded as synonymous with 'good discipline' (van Wyk, 2001). In South Africa, although corporal punishment has been abolished, Maree (2004) points out that it is however clear that not all schools abide by this ban. With the democratisation of South Africa after 1994, laws were put in place to outlaw the use of corporal punishment in schools and regard it as an infringement of children's rights and therefore all stakeholders in education had to abide. It has emerged that most educators were not impressed with this abolishment but they fear its use in schools because of its legal implications. This paper has discussed the meaning of corporal punishment in South African schools, sourcing from local and international literature; it also discussed the legal implications of the use of corporal punishment in South African schools by highlighting important legislation against the use of corporal punishment.

Furthermore, the article addressed the effects of the ban of corporal punishment on school discipline. Positive disciplinary practices which may be employed in the absence of corporal punishment were also discussed. In the same vein, the crucial role played by educators in managing discipline was highlighted in order to present alternatives to educators in a post-corporal punishment era. The main argument that the escalating lack of discipline in schools is mainly due to the banning of corporal punishment was investigated through the use of individual in-depth interviews with school principals of the sampled schools and corroborated with focus group discussions with educators in these schools. Participants expressed their knowledge with regards to laws on corporal punishment and indicated their willingness to come up with their own alternative means of discipline that will not infringe on the learners rights. These possible suggestions will accordingly and eventually assist in restoring the culture of teaching and learning in schools that has been lost with the banning of corporal punishment.

\section{References}

Adams-Anthony, P.C. (2004). An investigation into learner discipline at Silverlea primary schools, M-Tech Thesis, Cape Technikon.

Bauer, G. B., Dubanoski, R., Yamauchi, L. A \& Honbo, K. A .M. (1990). Corporal punishment And the schools. Education and Urban Society, 22: 285-299.

Blandford, S. (1998). Managing discipline in schools. London: Routledge.

Charles, C.M. (2007). Today's best classroom management strategies: Paths to positive discipline. Boston: Pearson.

Cohen, L., Manion, L. \& Morrison, K. (2008). Research methods in education (6th ed.) Routledge: London.

Creswell, J. W. (2009). Research design: qualitative, quantitative, and mixed methods approaches (3rd ed). London: SAGE.

Fouche, C. B. \& Delport C. S. L. (2003). 'Introduction to research process', in n Delport C. S. L,

De Vos, A. S. Fouche' C. B \& Strydom H (eds). Research at grass roots. Pretoria: Van Schaik.

Greeff, M. (2003). 'Information collection: interviewing', in Delport C. S. L, De Vos, A. S.

Fouche' C. B \& Strydom H (eds), Research at grass roots. Pretoria: Van Schaik.

Harber, C. (2001). Schooling and violence in South Africa: creating a safer school. Intercultural Education, 12: 261-271.

Hunt, J. (1999). Is hitting the "normie's" normal method of punishment? [Online]. Available: http://www.mlobe.com/ra/ra 8/spanking.htm.

Johnson Frankenberg, S. J. \& Holmqvist, B. (2010). The care of corporal punishment: conceptions of early childhood discipline strategies among parents and grandparents in a poor urban area in Tanzania [Online]Available: http://chd.sagepub.com/ content/17/4/455.

Joubert, R., De Wall, E., and Rossouw, J. P. (2004.) Discipline: Impact on access to equal educational opportunities. Perspectives in Education, 22(3): 77-87.

Jwan, J. O. (2011). In the best interest of the student: perceptions and implications for leadership practices in secondary schools in Kenya. Management in Education, 25(3): 106-111.

Le Mottee, S. (2005). Avoiding polarisation-building healthy relationships at school by developing approaches to school discipline which build a culture of learning and teaching [online]. Paper presented at the national Union of Educators Conference. [Online] Available: url:http//www.eisa.org.za/EISA/ education/slm2005.htm.

Makapela, L. (2006). Learners claim cane still used. Daily Dispatch, 10 May.

Maphosa, C. \& Shumba, A. (2010). 'Educators' disciplinary capabilities after banning of corporal punishment in South African schools', South African Journal of Education, vol.30 (3), 387-399.

Maree, J. C. (1999). Spoil the rod, spare the child: some views on corporal punishment in South Africa. Acta Criminologica: South African Journal of Criminology, 12 (2), 56-64.

Maree, J. C. (2004). Hitting the headlines - The Evil on corporal punishment in South Africa lifted. Act Criminologica, 17(3): 72-84.

Masitsa, G. (2008). 'Discipline and disciplinary measures in the Free State township schools: unresolved problems'. Acta academica, 40(3): 234-270.

Matoti, S. N. (2010). 'The unheard voices of educators: perceptions of educators about the state of education in South Africa', South African Journal of Higher Education, 24(4): 568-584. 
McClure, T. E \& May, D. C. (2008). Dealing with misbehaviour at schools in Kentucky: theoretical predictors of use of corporal punishment. Youth and society, 39(3): 406-429.

McMillan, J. H. \& Schumacher, S. (2006). Research in education: evidence-based inquiry (6th ed), Boston: Pearson.

McMillan, J. H. \& Schumacher, S. (2010). Research in education: evidence-based inquiry (7th ed), Boston: Pearson.

Middleton, J. (2008). The experiences of corporal punishment in schools, 1980-1940. History of Education, 37(2): 253-275.

Mokhele, P. R. (2006). 'The teacher-learner relationship in the management of discipline in public high schools', Africa Education Review, 3(1) \&2: 148-159.

Morrell, R. (2001). Corporal punishment in South African schools: a neglected explanation for its persistence. South African Journal of Education, 21(4): 292-299.

Mouton, J. (1996). Understanding social research. Pretoria: Van Schaik.

Mtsweni, J. (2008). The role of educators in the management of school discipline in the Nkangala Region of Mpumalanga, MEd dissertation, University of South Africa.

Naong, M. (2007). 'The impact of the abolition of corporal punishment on teacher morale: 1994-2004', South African Journal of Education, 27(2): 283-300.

Ndamani, P. L. (2008). 'Factors contributing to lack of discipline in selected secondary schools in the Mangaung Area of Bloemfontein and possible solutions', Interim: Interdisciplinary Journal, 7(2): 177-197.

Olley, R .I., Cohn, A., \& Cowan, K. C. (2010). 'Promoting safe schools and academic success: moving your school from punitive discipline to effective discipline', National Association of School Psychologists, 39(1): 7-8.

Owen, S. S. (2005). The relationship between social capital and corporal punishment in schools: a theoretical inquiry. Youth and Society, 37(1): 85-112.

Paolucci, E. O. \& Violato, C. (2004). A meta-analysis of the published research on affective, cognitive and behavioural effects of corporal punishment. Journal of Psychology, 138(3): 197-221.

Pinheiro, P. S. (2006). World Report on violence against children, Independent expert for United Nations in Johnson Frankenberg, S.J. \& Holmqvist, B. (2010). The care of corporal punishment: conceptions of early childhood discipline strategies among parents and grandparents in a poor urban area in Tanzania [Online] Available: http://chd.sagepub.com/content/17/4/455.

Porter, L. (2004). Behaviour in schools: Theory and practice for teachers. Open University Press: Maidenhead.

Porteus, K., Vally, S. \& Ruth, T. (2001). Alternatives to corporal punishment. Wits Education Policy Unit/SA Human Rights Commission/Heinemann: Sandown.

Ragin, C. C. \& Amoroso, L. M. (2011). Sociology for a new century: Constructing social research (2nd ed), London: SAGE: Pine Forge Press.

Republic of South Africa, Department of Education. (2000). Alternatives to corporal punishment. Pretoria: Government Printers.

Republic of South Africa. Constitution of the Republic of South Africa Act 108 of 1996. As adopted on 8 May 1996; amended on 110ctober 1996 by the Constitutional Assembly. Pretoria: Government Printers.

Republic of South Africa. South African Schools Act 84 of 1996. Government Gazzette, Vol. 378 No. 17678 (18 December 1996). Pretoria: Government Printers.

Republic of South Africa. The National Education Policy Act 27 of 1996. Pretoria: Government Printers.

Rogers, B. (1998). You know the fair rule: strategies for making the hard job of discipline. Pitman: London.

Soneson, U. (2005). Ending corporal punishment of children in South Africa: I want her to talk with me when I make a mistake. Save the children Sweden: Pretoria.

Squelch, J. M. (2000). Discipline. Pretoria: CELP

Strauss, M. A. \& Donnelly, D. A. (2001). Beating the devil out of them: corporal punishment in American families and its effect on children. New Brunswick, NJ: Transaction Publishers.

Strauss, M. A. (1994). Beating the devil out of them: Corporal punishment in American families. Califonia: Jossey-Bass Publishers.

United Nations. (1984). Universal Declaration of Human Rights. (1948). [Online] Available: http://www.ohchr.org/EN/UDHR/Documents/ UDHR_Translations/eng.pdf. [date accessed 21 April 2014].

United Nations. (1998). International Convention on the Rights of the Child. Eastern European Adoption Coalition.

United Nations. (2012). Guidelines on Human Rights Education for Secondary Schools systems. http://www.osce.org/odihr/93969? download=true [date accessed 21 April 2014].

United Nations. (1990) The African Charter on the Rights and Welfare of the Child, OAU Doc. CAB/LEG/24.9/49. Entered into force Nov 1999.

United Nations. The United Nations Committee on the Rights of the Child. [Online] Available: http://www.crin.org/en/guides/uninternational-system/collittee-rights-child. [date accessed 21 April 2014]..

Van Wyk N. (2001). Perceptions and practices of discipline in urban black schools in South Africa. South African Journal of Education, 21(3): 195-201.

Zulu, B. M. \& Urbani, G van der Merwe, A \& van der Walt, J. L. (2004). Violence as an impediment to a culture of teaching and learning in South African schools. South African Journal of Education, 24: 170-175. 